\title{
L2 Learners' Strategic Mental Processes during a Listening Test $^{1}$
}

\author{
Naoko Taguchi \\ Minnesota State University-Akita, Japan
}

This study offers some insights into second language learners' strategic mental processes during a listening comprehension test. Fifty-four Japanese college students (26 males and 28 females) in an intensive English program took an English listening test and completed a strategy questionnaire immediately after the test. The questionnaire consisting of 42 Likert-scaled items and four openended questions addressed the students' perceptions of listening strategies used for recovering from comprehension breakdown, compensating for comprehension, and reducing testing anxiety. The questionnaire also asked about the elements that caused comprehension difficulty for the students. The results of the Likert-scaled item section revealed a statistically significant difference between proficient and less proficient listeners in their perceived use of top-down strategies and reported elements of listening difficulty, but no difference in their use of repair, affective, or bottom-up strategies. Analyses of the open-ended responses showed that proficient listeners identified a greater range of strategies.

本研究では、集中英語課程に所属する日本人大学生 54 人（男子 26 人、 女子 28 人）が英語のリスニングテストを受け、そのあとすぐにリスニングス トラテジーに関するアンケートに記入した。アンケートは4 2 のリカートスケ 一ルアイテムと 4 つの記述式アイテムから成り、学生がテストの最中効果的に 英語を聞き取るため、また、テスト不安を少なくするためにどのようなストラ テジーを使ったかを聞いた。また、アンケートは、どのような要素が聞き取り を困難にしたかについても聞いた。リカートスケールアイテムの分析の結果、 テストスコアの良い学生とその他の学生を比べて、トップダウンストラテジー の使い方とリスニングを困難にする要素に違いがあることが分かったが、リペ ア、アフェクテイブ、ボトムアップストラテジーの使い方には違いは見られな かった。記述式アイテムの分析からは、テストスコアの良い学生はより幅の広 いストラテジーを使っていることが分かった。 


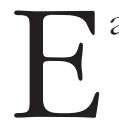

arly interest in L2 listening research stemmed from a theory that mere exposure to comprehensible input would enhance listening skills and promote language acquisition (Krashen, 1985). Recently, this exclusive attention to input has shifted to how learners process the input. Understanding what strategies learners use and what difficulties they experience has become an integral part of listening research. Information gleaned from such research is considered useful because it provides better insights into learners' listening ability and helps make their listening efficient. Thus, there is a growing interest in clarifying listeners' mental processes, identifying facilitative strategies, and incorporating them into classroom activities (Mendelsohn, 1995; Thompson \& Rubin, 1996; Vandergrift, 1999). Although previous research has examined listeners' metacognitive processes during different tasks, little research has been done to investigate strategies used while taking a listening test. Since the testing situation could have a considerable impact on learners' strategy use, it is important to understand what successful listeners actually do during a listening test. Thus, the purpose of this study was to find out if there were differences between proficient and less proficient listeners in their strategic mental processes during a test.

\section{Background}

Research in listening comprehension strategies has evolved in the course of a number of studies in the field of language learning strategies (O'Malley, Chamot, \& Walker, 1987; Oxford \& Crookall, 1989; Wenden \& Rubin, 1987). Language learning strategies are defined as deliberate techniques employed by learners to enhance the use of the target language information (Oxford, 1990). Previous research has identified three strategy categories: cognitive, metacognitive, and affective, and has revealed that the choice of a strategy is greatly influenced by learner proficiency (Conrad, 1985; O'Malley \& Chamot, 1990; Rost \& Ross, 1991).

Cognitive strategies are problem-solving that learners employ to manipulate their learning tasks and facilitate acquisition of knowledge or skills (Derry \& Murphy, 1986). Examples of cognitive strategies in the field of listening include predicting, inferencing, elaborating, and visualization. Previous research has largely focused on two types of cognitive strategies, bottom-up and top-down, and confirmed that proficient students use more top-down strategies than less proficient listeners (Clark, 1980; Conrad, 1985; Tsui \& Fullilove, 1998; O'Malley, Chamot, \& Kupper, 1989). Vandergrift's (1998) study of French learners 
showed that weak learners translated more and allocated more attention to decoding individual words, while strong listeners focused on larger chunks. Overreliance on bottom-up processing seemed to cause overloading of short-term memory and discouraged the use of more important strategies such as predicting or inferencing. Vogely (1998) recently investigated the listening anxiety of college students of Spanish. The subjects focused on understanding and translating every word they heard, and they reported frustration and anxiety when they could not translate everything. Bottom-up processing such as word-by-word decoding could make listeners anxious and consequently hinder their listening process.

Another type of strategy, metacognitive, is a management technique that learners use to control their learning through planning, monitoring, evaluating, and modifying (Rubin, 1987). Baker and Brown (1984) distinguished two aspects of metacognitive ability: knowledge on cognition (i.e., knowing what') and regulation of cognition (i.e., knowing how'). The first aspect relates to the learners' conceptualization about their listening process, namely their awareness of what is going on and what is needed to listen effectively. Previous research has examined learners' persistence when encountering comprehension difficulty as a factor influencing effective listening. Learners' persistence was related to two types of metacognitive strategies: self-management (i.e., controlling language performance) and self-monitoring strategies (i.e., checking one's comprehension) (O'Malley \& Chamot, 1990). According to O'Malley et al. (1989), strong listeners use more repair strategies; when comprehension fails, strong listeners make an effort to redirect their attention back to the task quickly and keep on listening actively, while weak listeners stop listening further.

According to Nagle and Sanders' (1986) model of listening comprehension, when raw speech enters the brain, the attention stage plays an important role in retaining the data in short-term memory, narrowing the focus, and initiating the information processing. Attention is an indispensable step for listening, as no storing and sorting of information could begin without it. Thus, attention recovery may influence successful comprehension. Proficient listeners show more persistence when listening through their active use of repair strategies.

The last category, affective strategies, includes attempts to enhance positive emotional reactions toward language learning (Chamot \& O'Malley, 1987). Oxford (1990) identified four types of facilitative socio-affective strategies: seeking social support, lowering anxiety, self-encouragement, and taking emotional temperature (i.e., averting negative emotions and making the most use of positive ones). The so- 
cio-educational model (Gardner \& MacIntyre, 1992, 1993) stressed that the learning context is directly related to learners' social-psychological factors: how learners feel and react to the learning experience. Therefore, the strategies used for affective control over learning experiences are considered to play an important role in L2 learning. Vandergrift (1996, 2000) documented that junior/senior high school students of French used more affective strategies as their course level increased. Aneiro (1989) also reported a significant correlation between low anxiety and high listening ability, suggesting that the use of affective strategies could facilitate listening.

In sum, preceding studies identified a variety of listening strategies and confirmed that proficient listeners used more metacognitive strategies such as self-monitoring or self-directing, and top-down cognitive strategies such as elaboration and inferencing. A positive relationship was also found between the use of affective strategies and listener proficiency.

While a vast body of research provides a reasonably well-formulated analysis of the listeners' strategic process and its relationship to listening ability, questions remain as to how listeners of different skill levels compare in different listening situations. Previous research has focused exclusively on classroom listening activities, and little research has been done to investigate other listening settings, such as testing situations, to understand learners' strategic involvement in the process. A testing situation could exhibit considerably different task characteristics and demands. Tests used for tracking, promotion, or certification purposes could cause considerable anxiety because the outcomes of the tests have a direct impact on the lives of the test takers. In a testing situation where learners are expected to perform accurately under time constraints, they may be discouraged from using certain strategies such as risk taking or monitoring. Strategies for affective control and concentration, on the other hand, might surface as strong, general test taking strategies. Therefore, it is important to find out whether the previous claims made about various listening strategies are confirmed in a testing situation. Such investigation will add to a growing body of literature focused on the relationship between strategy use and task characteristics (Cohen, 2000).

Information on learners' strategic involvement during test taking could provide additional insights into the process that learners use to derive correct answers (Bachman, 1990; Cohen, 1998). There is growing interest in analyzing test taking from a fstrategic perspective because such information could help us understand what test items are really testing and what difficulties the test takers encounter (Buck, 1990; Yi'an, 
1998). Such an investigation will supplement traditional test analysis by providing insights into why and how individual items are answered correctly.

Furthermore, in most research, learners are designated as proficient or less proficient listeners based on a separate measurement (e.g., a course grade, general language test, or teacher evaluation), but not based on their performance on the specific listening task to which they applied their strategies. Since information on learners' strategies and their abilities comes from different sources, the relationship between the two variables may be considered indirect. Thus, investigating how strong learners listened during test on which they achieved a high score may show a more direct relationship between strategy use and listening ability. Although several studies have investigated the relationship between the use of specific strategies and test performance (Cohen, Weaver, \& Li, 1996), the corpus of such data is still limited. Few studies have documented that frequent use of particular strategies is directly associated with an increase in score. Thus, additional research in this area could add to our understanding.

Finally, listeners' evaluations of which strategies are difficult to apply or what makes a text difficult could enhance our understanding of listeners' conceptualizations of the listening process. As previous literature states, certain textual elements (e.g., recognizing combinations of words, dividing the stream of speech, morphological complexity) cause comprehension difficulty and affect strategy use (Rubin, 1994; Vogely, 1995). Therefore, the relationship between learners' strategy choice and their confidence in using the strategies is worth investigating.

\section{Purpose}

The current study examines strategic mental processes of Japanese learners of English during a listening test, focusing on two subproblems: the types of listening strategies usedand the reported elements of listening difficulty. The subproblems were explored by the following five research questions and the researcher's alternative hypotheses:

RQ1. Are there differences between proficient and less proficient listeners in their perceived use of repair strategies?

H1. Proficient listeners use more repair strategies than less proficient listeners.

RQ2. Are there differences between proficient and less proficient listeners in their perceived use of affective 
strategies?

H2. Proficient listeners use more affective strategies than less proficient listeners.

RQ3. Are there differences between proficient and less proficient listeners in their perceived use of top-down compensatory strategies?

H3. Proficient listeners use more top-down strategies than less proficient listeners.

RQ4. Are there differences between proficient and less proficient listeners in their perceived use of bottom-up compensatory strategies?

H4. Proficient listeners use fewer bottom-up strategies than less proficient listeners.

RQ5. Are there differences between proficient and less proficient listeners in their reported elements of listening difficulty?

H5. Proficient listeners report less listening difficulty than less proficient listeners.

\section{Method}

\section{Participants}

The participants were 54 first year Japanese students enrolled in the Intensive English Program (IEP) at a branch American university in northern Japan. There were 26 males and 28 females with an average age of 18.7 and a range of 18 to 26. The IEP is divided into two parts: the Focal Skills Program and the English for Academic Purposes Program. The initial part of the IEP, the Focal Skills Program, consists of three modules: Listening, Reading, and Speaking/Writing. The objective of the Focal Skills Program is to help students first achieve proficiency in receptive skills (i.e., listening and reading), prior to production skills (i.e., speaking and writing). The participants in this study were first year students enrolled in the first four-week session of the Listening Module. They received 20 hours of English instruction per week aimed at developing their listening skills. Prior to placement into the module, they had received at least six years of formal English education in Japan, between two to four hours per week on the average. However, due to the instructional emphasis on grammar, the participants' overall listening ability was considered as beginning to intermediate level. 


\section{Materials}

\section{Pilot Study}

A pilot study was conducted in order to address the reliability of the listening questionnaire and revise the questionnaire accordingly. The participants in the pilot study were 39 males and 34 females enrolled in the same Focal Skills Listening Module a year before the main study. At the end of the first four-week session, they took the Focal Skills Listening Test (Focal Skills Resources, 1990) and completed a listening questionnaire in Japanese consisting of two parts: Likert-scaled items and open-ended questions.

The Likert-scaled items were on an ordinal scale ranging from Strongly Agree (5) to Strongly Disagree (1). The 30 items were divided into 4 categories: repair, affective, and compensatory strategies, and listening difficulty. Repair strategies (six items) were defined as techniques used to recover from comprehension breakdown. The three affective items were from the socio-affective strategies (Oxford, 1990): lowering anxiety, self-encouragement, and taking emotional temperature (i.e., averting negative emotions). Compensatory strategies consisted of five bottom-up and five top-down strategies that were used to facilitate the comprehension process. Bottom-up strategies included attending to smaller units of the text. Top-down strategies included using contextual information or prior knowledge to comprehend the main idea of the text. Difficulty area included a set of textual elements such as soundletter correspondence, relating vocabulary to meaning, text gist, or speed of speech.

The items in the repair, compensatory, and difficulty categories were directly taken from the Metacognitive Awareness Strategy Questionnaire (MASQ) (Carrell, 1989). The MASQ was originally developed to analyze L2 learners' reading process. Vogely (1995) adapted it to analyze the listening process of L2 Spanish learners. The three affective strategies were added to the MASQ by the researcher in order to account for the testing situation. The MASQ items were translated by the researcher and administered in Japanese. Another Japanese instructor of English checked the quality of the translation.

The second section of the questionnaire had four open-ended questions corresponding to the four sub-categories of the Likert-scaled item section. The questions asked learners to report repair, affective, and compensatory strategies, and the areas of listening difficulty.

The questionnaire was revised based on the reliability assessment. Item analysis was conducted in order to check the degree of consensus regarding the direction of each questionnaire category (i.e., positive/ negative response). Pearson product-moment correlation coefficients 
were calculated between item scores and total category scores. According to Mueller (1986), a zero or negative correlation indicates that the item is discriminating respondents in a different way from the total score or working against the discrimination, and thus is subject to revision. Jaeger (1993) also states that correlation coefficients lower than 0.40 indicate weak relationships. In the pilot study, all items had correlation coefficients between 0.50 and 0.80 and thus were not revised.

Internal consistency reliability of the questionnaire was estimated using the Spearman-Brown Prophecy formula (Brown, 1996). The adjusted full-questionnaire reliability was 0.73 . The reliability estimates for the five sub-categories were $0.51,0.33,0.79,0.68$, and 0.88 for repair, affective, top-down, bottom-up, and difficulty area, respectively. Due to the low reliability, the number of items in repair, affective, and compensatory categories was increased.

The open-ended section provided information to decide what items to add to each section. The students who achieved a high score on the listening test were identified by using a mean split $(n=34)$, and their responses to each strategy category were compiled. The strategies that were frequently reported by the students were added to each category.

\section{Listening Questionnaire}

The revised questionnaire had 42 Likert-scaled items and 4 open-ended questions (Appendix 1). The Likert-scaled items consisted of eight repair, eight affective, seven top-down, eight bottom-up, and eleven difficulty items (see Appendix 2 for the table of specifications). When administered in the present study, the internal consistency reliability was 0.80 for the full questionnaire, using the Spearman-Brown Prophecy formula. The reliability estimates were $0.73,0.73,0.83,0.70$, and 0.86 for repair, affective, top-down, bottom-up, and difficulty area, respectively.

The same open-ended questions used in the pilot study were asked in the main study. As Chamot, Kupper, and Impink-Hernandez (1988) note, quantitative analyses of listening process can offer only a superficial picture. Thus, the purpose of this open-ended section was to obtain qualitative data on the participants' mental processes while listening and to supplement the information gleaned from the quantitative analysis. The four questions were:

1. What did you do when you didn't understand something during the test?

2. What did you do to relax for the test?

3. What did you focus on in order to compensate for your 
listening during the test?

4. What kinds of things were difficult for you while listening?

\section{Focal Skills Listening Test}

The Focal Skills Listening Test (Focal Skills Resources, 1990) was used to designate strong and weak listeners. The test also functioned as listening input on which the participants could reflect in terms of their mental processes while responding to the questionnaire items. The test was approximately 30 minutes long and had 60 short dialogues followed by yes-no questions. It is a commercially available test designed for the Focal Skills Program. The published K-R 21 reliability estimate of internal consistency of the test is 0.91 , and the standard error of measurement (SEM) is 3.02. The test aims to assess listeners' basic comprehension skills over a variety of daily topics in family, school, and social situations. The test score produces an interval scale from zero to 60, one point being assigned per correct answer. In the current study, the reliability estimate was 0.75 using K-R 21, and the SEM was 3.65.

\section{Procedures}

The study was conducted in the spring of 2000 at the end of the first four-week session of the academic year in the IEP. The participants took the Focal Skills Listening Test in the listening lab at their university in 30 minutes. Immediately after the test, they were asked to complete the listening questionnaire in approximately 15 to 20 minutes. The written directions for the questionnaire were in Japanese. The subjects were reminded to think about the listening test they had just taken while responding to the questionnaire items.

\section{Analysis}

This study compared the strategic mental processes of proficient and less proficient Japanese learners of English during a listening test. Listening proficiency, the independent variable in the study, was operationalized as the scores on the Focal Skills Listening Test with an interval scale between zero and 60. Scores were dichotomised into two groups by a mean split representing high and low scoring groups. Thus, learner proficiency was treated as a nominal variable with two levels: proficient and less proficient.

Learners' strategic mental process was operationalized in terms of their perceived listening strategy use and listening difficulty. The depen- 
dent variables were the four areas of listening strategies: repair, affective, top-down compensatory, and bottom-up compensatory strategies. Listening difficulty was the fifth dependent variable. The five variables were measured by the Likert-scaled items of the listening questionnaire, which had an ordinal scale of one to five. The ordinal scores were transformed into interval scores by computing the sum of the item scores within each variable category. A high interval score indicated frequent use of the specific strategy or increased perception of difficulty. The five dependent variables were also addressed qualitatively by summarizing the responses to the open-ended section of the questionnaire.

The responses to the Likert-scaled items were compared between proficient and less proficient listeners by using a one-tailed t test for two independent samples. The t test was selected because it is a type of parametric test that is more powerful for hypothesis testing than non-parametric tests (Hatch \& Lazaraton, 1991). In addition, data met the underlying assumptions for using the $t$ test. There were two levels of one independent variable to compare, and each subject was assigned to only one group. The data were considered as continuous because the ordinal scores of the questionnaire items were summed within each category. In addition, normality of score distribution of each group was confirmed by the Shapiro-Wilks' test at the significance level of 0.01. Finally, the Levene's test was applied to check the assumption of homogeneity of variance. The variance of the two groups was equal in each of the five variables tested at a significance level of 0.01 .

Prior to applying the $t$ test for the statistical analyses, based on the previous conventions, the significance level was set at 0.05 . However, because the current study used five $t$ tests (i.e., one t test per dependent variable), the significance level was adjusted to 0.01 using the Bonferroni correction by dividing the alpha level of 0.05 by the total number of comparisons (Hatch \& Lazaraton, 1991; Jaeger, 1993; SPSS, 1998). Thus, the statistical results reported in this paper are based on the adjusted alpha level of 0.01 in order to avoid the error of rejecting the null hypothesis when it should not have been rejected (Brown, 1990).

\section{Results and Discussion}

This section presents descriptive statistics of the Focal Skills Listening Test and the listening questionnaire, and discussions of the first and second subproblems. 


\section{Descriptive Statistics}

The descriptive statistics of the Focal Skills Listening Test and the listening questionnaire are presented in Tables 1 and 2 . The mean and median of the test were 37.00. The mean and median were equivalent, and the scores had a normal distribution ranging from 23.00 to 56.00. Because the mean is the best measure of central tendency, the participants were divided into two groups by a mean split. Twenty-eight students who scored 37 or higher were called proficient listeners (mean $=43.36, \mathrm{SD}=$ $4.68)$, and the students who achieved a score of lower than $37(\mathrm{n}=26)$ were called less proficientd listeners $($ mean $=31.23, \mathrm{SD}=3.79)$.

$$
\begin{gathered}
\text { Subproblem One: Are There Differences } \\
\text { in Perceived Strategy Use? }
\end{gathered}
$$

Table 1: Descriptive Statistics of the Focal Skills Listening Test

\begin{tabular}{llllllll}
\hline Group & N & Mean & Median & SD & Min & Max & Range \\
\hline Total & 54 & 37.00 & 37.00 & 7.03 & 23 & 56 & $0-60$ \\
Proficient & 28 & 43.36 & 41.50 & 4.6837 & 56 & \\
Less proficient & 26 & 31.23 & 32.00 & 3.7923 & 36 & \\
\hline
\end{tabular}

Note: $\mathrm{N}$ means the number of participants. The test had 60 items in total, so the range means the lowest and highest score possible.

Table 2: Descriptive Statistics of the Listening Questionnaire

\begin{tabular}{lccccccc}
\hline Category & K & Mean & Median & SD & Min & Max & Range \\
\hline Repair & 8 & 29.53 & 30.00 & 4.12 & 20 & 39 & $8-40$ \\
Affective & 8 & 25.10 & 25.00 & 5.5814 & 39 & $8-40$ \\
Top-down & 7 & 25.94 & 27.00 & 4.8616 & 35 & $7-35$ \\
$\begin{array}{l}\text { compensatory } \\
\text { Bottom-up }\end{array}$ & 8 & 26.26 & 26.00 & 4.01 & 18 & 35 & $8-40$ \\
$\begin{array}{l}\text { compensatory } \\
\text { Difficulty }\end{array}$ & 11 & 35.53 & 37.00 & 7.30 & 18 & 50 & $11-55$ \\
\hline
\end{tabular}

Note: Each Likert-scaled item had an ordinal measurement of 1-5, so the range refers to the lowest and highest score possible in each strategy category. $\mathrm{K}$ means the number of questionnaire items in each category. The number of participants was 54 .

Subproblem one in this study asked whether there were differences between proficient and less proficient listeners in their perceived use of repair, affective, top-down, and bottom-up listening strategies. This subproblem was addressed quantitatively and qualitatively, based on the results of the Likert-scaled item section and the open-ended question section. 


\section{Likert-Scaled Item Section}

Based on the previous literature, it was hypothesized that proficient listeners use more repair, affective, and top-down strategies and fewer bottom-up strategies. Having met the underlying statistical assumptions, the responses to the Likert-scaled items were compared between proficient and less proficient listeners by using the one-tailed t test for two independent samples $(\mathrm{a}=0.01$, adjusted alpha level according to the Bonferroni correction). As shown in Table 3, the t test results revealed a significant difference in the use of top-down strategies only $(t=2.53$, $\mathrm{p}<0.01$ ), with a moderate effect size of 0.70 based on the Cohen conventions (Cohen, 1988; Howell, 1997).

Although the t test results showed that significantly more proficient listeners used top-down strategies, there seems to be a great discrepancy among the individual top-down strategies. Table 4 summarizes the percentages of the proficient and less proficient listeners who chose Strongly Agree (5) or Agree (4) for each Likert-scaled top-down

Table 3: t Tests for Repair, Affective, and Compensatory Strategies

\begin{tabular}{|c|c|c|c|c|}
\hline Strategy category & Group & Mean & $\mathrm{SD}$ & t value (one-tailed) \\
\hline \multirow[t]{2}{*}{ Repair } & Proficient & 30.50 & 3.94 & \multirow{2}{*}{1.85} \\
\hline & Less proficient & 28.44 & 4.18 & \\
\hline \multirow[t]{2}{*}{ Affective } & Proficient & 25.00 & 5.34 & \multirow{2}{*}{-0.15} \\
\hline & Less proficient & 25.20 & 5.93 & \\
\hline \multirow[t]{2}{*}{ Top-down } & Proficient & 27.46 & 3.82 & \multirow{2}{*}{$2.53^{* *}$} \\
\hline & Less proficient & 24.24 & 5.40 & \\
\hline \multirow[t]{2}{*}{ Bottom-up } & Proficient & 26.75 & 4.30 & \multirow{2}{*}{0.92} \\
\hline & Less proficient & 25.72 & 3.82 & \\
\hline
\end{tabular}

Note: *** $\mathrm{p}<0.01$.

item. Among the seven strategies, "understanding the overall meaning" (Item 23 ) received the strongest response ( $80 \%$ or more), while only $25 \%$ or fewer of the students in both groups reported "relating each conversation to prior experience" (Item 38). In addition, proficient listeners used some strategies much more frequently than less proficient 
listeners. Approximately $80 \%$ of the proficient listeners were in favor of "paying attention to the speakers' tone of voice and intonation" (Item 27), while the percentage of the less proficient listeners was less than $30 \%$. Similarly, "Imagining the setting" (Item 13) and "attending to the tone of conversation" (Item 28) were employed notably more often by proficient listeners, suggesting their effective use of pragmatic and contextual clues.

The post hoc analysis of bottom-up strategies showed a similar tendency (Table 5). Certain bottom-up strategies were used notably more often than others. "Trying to find familiar vocabulary" (Item 7) received the strongest response from both groups ( $80 \%$ or more), while other strategies such as "focusing on grammatical structures" (Item 25) and

Table 4: Percentages of the Learners Who Chose Agree/Strongly Agree

for Each Top-Down Strategy

Questionnaire items

8. I tried to predict the questions coming after each conversation.

13. I tried to imagine the setting of each conversation.

23. I focused on understanding the overall meaning.

27. I paid attention to speakers' tone of voice and intonation.

28. I paid attention to the overall tone of the situation.

38. I tried to relate each conversation to my own experience in order to understand the conversation.

39. I was thinking about the relationship between the speakers.
Proficient Less proficient

75.0

60.0

78.6

56.0

97.2

80.0

78.6

28.0

85.7

64.0

25.0

20.0

60.7

60.0

"paying attention to particular parts of speech" (Item 16) received weak responses (approximately 30\% or less). These descriptive analyses suggest that individual top-down and bottom-up strategies, rather than the dichotomized strategies, could be factors contributing to effective listening. Specific strategies may work differently in distinguishing successful and unsuccessful listeners.

\section{Open-Ended Responses}

The participants' responses to the open-ended questions were com- 
Table 5: Percentages of the Learners Who Chose Agree/Strongly Agree

for Each Bottom-Up Strategy

6. While listening, I paid attention to the vocabulary that was repeatedly used in the conversation.

60.7

89.3

60.7

35.7

39.3

21.4

57.1
76.0

80.0

52.0

24.0

28.0

24.0

8.0

31. I focused on understanding the meaning of each word.

piled and compared between proficient and less proficient listeners. Tables 6 through 8 display the mean frequency of repair, affective, and compensatory strategies reported. Proficient listeners reported a greater variety of strategies in all categories than less proficient listeners. Although both groups reported that they guessed meaning when their comprehension failed (Table 6), proficient listeners further elaborated how they guessed (i.e., guessing from tone of conversation, speakers' voice/intonation, and test questions).

One of the most notable differences in the affective strategies is that considerably more proficient listeners reported that they were not nervous about the test (Number 1 in Table 7). This may be because

\section{Table 6: Mean Frequencies of Repair Strategies Reported by the Learners}

Q: What did you do when you didn't understand something?

Proficient Less proficient-

1. I attended to the next segment.

2. I just guessed.

3. I guessed from the context (before and after).

4. I guessed from the tone of conversation.

5. I guessed from speakers' tone of voice and intonation.

6. I guessed from vocabulary.

7. I guessed from the question.

8. I tried not to dwell on the part I didn't understand. Total frequency
$0.04(1)$

$0.11(3)$

$0.25(7)$

$0.18(5)$

$0.04(1)$

$0.07(2)$

$0.18(5)$

(30)
$0.21(6)$
$0.05(1)$

$0.23(6)$

$0.23(6)$

$0.00(0)$

$0.00(0)$

$0.19(5)$

$0.00(0)$

$0.15(4)$

Note: The numbers in the parentheses represent raw counts. 
Table 7: Mean Frequencies of Affective Strategies

Reported by the Learners

\begin{tabular}{lcc}
\hline Q: What did you do to relax for the test? & Proficient & Less proficient \\
\hline 1. I wasn't nervous. & $0.25(7)$ & $0.05(1)$ \\
2. I spoke with my American friends before the test. & $0.14(4)$ & $0.05(1)$ \\
3. I chewed gum. & $0.00(0)$ & $0.08(2)$ \\
4. I was singing my favorite songs in mind. & $0.04(1)$ & $0.08(2)$ \\
5. I took a walk or exercised before the test. & $0.07(2)$ & $0.15(4)$ \\
6. I kept saying to myself, "I can pass the test." & $0.07(2)$ & $0.00(0)$ \\
7. I tried not to think that it's a test. & $0.14(4)$ & $0.00(0)$ \\
8. I focused my eyes on one point. & $0.04(1)$ & $0.05(1)$ \\
9. I had a cup of coffee before the test. & $0.04(1)$ & $0.05(1)$ \\
10. I took a deep breath. & $0.04(1)$ & $0.00(0)$ \\
11. I was thinking about something fun. & $0.00(0)$ & $0.05(1)$ \\
12. I closed my eyes. & $0.07(2)$ & $0.20(5)$ \\
Total Frequency & $(25)$ & $(18)$ \\
\hline
\end{tabular}

Table 8: Mean Frequencies of Compensatory Strategies Reported by the Learners

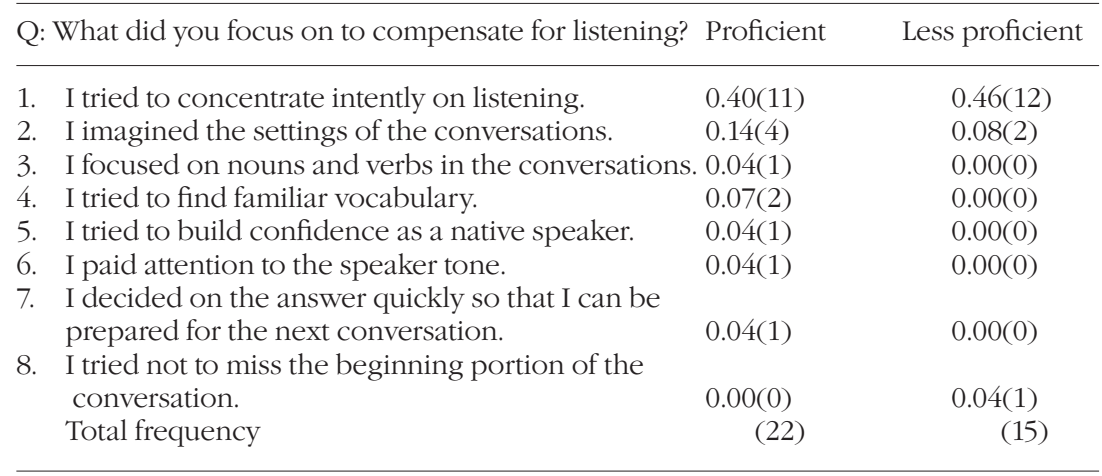

strong listeners had confidence in their ability or already knew how to control their test anxiety. Other affective strategies such as positive self-talk (Number 6) and being less conscious about the test (Number 7) were also observed exclusively in the responses of proficient listeners. In addition, a larger portion of proficient listeners reported that they spoke with their American friends in order to mentally prepare for the test (Number 2).

In the area of compensatory strategies, proficient listeners identified more different types of strategies (Table 8). The reported strategies included both top-down (i.e., imagining the settings, paying attention to the speaker tone) and bottom-up (i.e., focusing on nouns and verbs, 
trying to find familiar vocabulary). Similar to the findings from the Likert-scaled section, individual strategies in both categories of cognitive strategies seem to deserve attention.

\section{Subproblem Two: Are There Differences in Difficulty Elements?}

The second subproblem was related to how proficient and less proficient listeners evaluated the listening task in terms of difficulty.

\section{Likert-Scaled Item Section}

The results of the one-tailed t test for two independent samples revealed that proficient listeners reported less listening difficulty, $\mathrm{t}(52)=-4.68$, $\mathrm{p}<0.01$, with a high effect size of 1.30 (Table 9).

Table 9: t Test for Difficulty Elements

\begin{tabular}{lccc} 
Group & Mean & SD & t value \\
\hline Proficient & 31.79 & 6.69 & $-4.68^{* *}$ \\
\hline Less proficient & 39.72 & 5.51 &
\end{tabular}

Note: $* * 0<0.01$

Table 10 summarizes the percentages of the proficient and less proficient listeners who chose Agree (4) or Strongly Agree (5) for each ifficulty item. Overall, considerably more weak listeners felt the listening task was difficult, and this tendency was consistent for all individual items. For both listener groups, "understanding the details of the conversation" (Item 26) and "relating each conversation to one's own experience" (Item 30) were difficult strategies to employ. Previous post hoc analyses on compensatory strategies also showed that the learners did not use these strategies. In addition, approximately $90 \%$ of the less proficient listeners felt "understanding pronunciation of each word" (Item 4) and "remembering the content of the conversation" (Item 41) were difficult. However, a majority of the proficient listeners felt that these two elements did not cause comprehension difficulty. 
Table 10: Percentages of the Learners Who Chose Agree or Strongly Agree for Each Difficulty Element

\begin{tabular}{lrc}
\hline \multicolumn{1}{c}{ Questionnaire items } & Proficient & Less proficient \\
\hline 4. Pronunciation of each word. & 46.4 & 92.0 \\
5. Understanding the main idea of each conversation. & 25.0 & 72.0 \\
11. Imagining the setting of each conversation. & 21.4 & 52.0 \\
14. Keeping up with the speed of the tape. & 25.0 & 64.0 \\
17. Understanding the combination of words into phrases. & 35.7 & 76.0 \\
19. Predicting the question coming after each conversation. & 60.7 & 92.0 \\
26. Understanding the details of the conversation. & 85.7 & 96.0 \\
30. Relating each conversation to my own experience. & 85.7 & 84.0 \\
34. Understanding the meaning of each word. & 35.7 & 56.0 \\
41. Remembering the content of the conversation. & 42.9 & 88.0 \\
42. Knowing when I understood & 35.7 & 68.0 \\
something and when I did not. & & \\
\hline
\end{tabular}

What is noteworthy in the present results is that, for less proficient listeners, there seems to be a greater gap between their perception of compensatory strategies and their actual application of the strategies. The post hoc analysis of top-down strategies revealed that $80 \%$ of the less proficient listeners focused on getting the overall meaning of the text; however, more than $70 \%$ of the same group also reported that understanding the main idea was difficult (Item 5). Other top-down strategies, "imagining the setting" (Item 11) and "predicting the question" (Item 19), showed similar tendencies, indicating that weak listeners could not use these strategies easily. It is suggested that being strategic means not only knowing which strategies to use but also how to use them effectively. The current results concur with Baker and Brown's (1984) distinction between declarative knowledge (i.e., knowledge of "what") and procedural knowledge (i.e., knowledge of "how"). Knowing that a certain strategy is useful may precede the ability to use it routinely.

\section{Open-Ended Responses}

Table 11 summarizes the mean frequencies of the difficulty elements reported by the participants. One notable finding is that considerably more weak listeners said "everything" was difficult (Number 8), suggesting that they could not pinpoint the specific areas of listening difficulty. This may be due to their low listening proficiency because some of them listed "speed of the conversation" as one of the difficulty areas. On the other hand, several proficient listeners identified vocabulary and specific linguistic features (i.e., parts of speech, grammatical functions) 
as difficulty areas.

Table 11: Mean Frequencies of Difficulty Elements Reported by the Learners

Q: What kinds of things were difficult for you while listening?

Proficient Less proficient

1. Concentration.

2. Understanding sounds.

3. The speed of the conversation.

4. Remembering the content.

5. The combination of words into phrases.

6. Vocabulary.

7. Hearing the conversation only once.

8. Everything.

9. Conversation is too long.

10. People's names.

11. Nouns and verbs.

\section{$0.07(2)$}

$0.04(1)$

$0.11(3)$

$0.00(0)$

$0.04(1)$

$0.43(12)$

$0.07(2)$

$0.04(1)$

$0.00(0)$

$0.00(0)$

$0.04(1)$

12. Grammatical functions (e.g., negation markers). Total frequency
$0.04(1)$
$0.00(0)$

$0.05(1)$

$0.38(10)$ 0.05(1)

$0.10(2)$

$0.27(7)$

$0.00(0)$

$0.31(8)$

$0.05(1)$

$0.05(1)$

$0.00(0)$

$0.00(0)$

(31)

\section{Conclusions and Implications for Future Research}

This study examined the conscious and strategic mental processes of Japanese learners of English during a listening test. The study was motivated by previous findings showing that strong and weak listeners have different mental and strategic involvement while listening. The study represented an attempt to find out whether such findings could be confirmed in a different listening situation such as testing. The study also provided a process-oriented perspective to language testing. It supplemented the traditional outcome-oriented testing practice by documenting the actual internal processes that the learners go through in order to arrive at answers. Interpretations of the results and implications for future research are presented below.

\section{Interpretation of Perceived Strategy Use}

The first four research questions addressed whether learners of different proficiency levels differ in their use of four types of strategies: repair, affective, top-down, and bottom-up. The results supported previous findings that suggest that proficient listeners use more top-down strategies, but did not support the claims about repair, affective, and bottom-up strategies. The present study revealed that strategic tendencies could 
interact with task/context characteristics (e.g., task goal, demands), in addition to acting with listener characteristics (e.g., proficiency). Replicating previous findings from classroom contexts, the current findings showed that, in a testing situation, learners might demonstrate different preferences toward specific strategy categories. During testing, learners tend to be strongly motivated toward the task and are concerned about the accuracy of their listening. As a result, test takers might actively try to sustain their concentration and to listen carefully for details. Similarly, in a testing situation, where the psychological demand is the major controlling element, affective strategies could function as general test taking strategies and are employed frequently regardless of learners' proficiency levels. Therefore, previous generalizations made about strategy use comparing strong and weak listeners may not apply to different listening settings with different demands.

This study also found that proficient learners use significantly more top-down strategies, suggesting that this strategy category might be a ffactor contributing to effective listening on the current task. This finding adds to the limited body of existing literature because, for this particular listening task, an explicit link was established between the use of certain types of strategies and performance on the listening test. An increase in the use of top-down strategies was found to be related to an increase in test scores, providing insights into how and why test items were answered correctly, in addition to who got the items correct.

Another implication gleaned from the current findings is the variation among individual strategies. Despite the statistical evidence that strong listeners use more top-down strategies, the post hoc analyses demonstrated that particular top-down and bottom-up strategies were used much more frequently by the proficient group than the less proficient group. The findings imply a need to look into individual compensatory strategies, rather than the dichotomized categories. Specific top-down and bottom-up strategies may contribute differently to discriminating successful and unsuccessful listeners. Looking into the existing variety in each compensatory category may be important to capture a picture of truly influential strategies.

The responses to the open-ended questions documented a wider range of repair, affective, and compensatory strategies reported by the proficient listeners. Strong listeners seem to be able to identify and elaborate the specific tactics they used. They seem to be more aware of their own listening process and to have better retrospective observation of their strategy use. As Wenden (1986) notes, appropriate choice and use of strategies requires metacognition. Future strategy research should expand the analytical categories to describe what learners know about 
their learning processes, and what they are capable of expressing.

The present study identified, both quantitatively and qualitatively, a set of strategies that are more strongly favored by high scoring listeners, and thus potentially contribute to effective listening. Additional research might provide evidence of whether or not teaching these strategies to weak listeners can actually improve their performance in testing. Such inquiry has great potential because it could provide an empirical basis to investigate, that is, whether strategies are actually teachable. It could offer a potential cause-effect link between strategy use and listening performance. A problem of strategy research is that it is difficult to determine the cause and effect relationship between strategy use and L2 performance, whether using certain strategies leads to better performance or vice versa. Therefore, instructional studies that can show which strategies actually improve performance will expand our understanding of the learning process. The set of potentially influential strategies identified in the present study could serve as a base line for future investigations.

\section{Interpretation of Listening Difficulty}

The fifth research question asked whether there are differences between proficient and less proficient listeners in their reported elements of listening difficulty. The results support the previous claim that structural and textual elements are sources of listening difficulty for less proficient listeners. These elements deserve instructional attention and are potential areas to be overcome in order to improve listening performance. Similar to strategy use, the responses to the open-ended questions revealed that proficient listeners possessed greater metacognitive awareness of their comprehension difficulty during the test.

The existing difference between the difficulty area and the actual use of strategies found in this study implies that comprehension difficulty could be the factor that discourages weak listeners from applying strategies successfully to their listening tasks. As shown in the post hoc analyses, although a large number of weak listeners reported trying to use top-down strategies, they also felt those strategies were difficult to use.

The gap between the perceived use and actual application of strategies may stem from the learners' lack of basic listening ability or experience in applying the strategies. The difference between proficient and less proficient listeners could lie in their ability to actually use the strategies rather than knowing which strategies they should use. Knowing which strategies to use and being able to use the strategies 
successfully may be two separate skills. Listeners' basic proficiency or strategy practice could greatly influence their ability to actually utilize the strategies in listening tasks. The present findings imply a need for further research to investigate the degree of confidence that proficient and less proficient listeners have when using the strategies, not only the types of strategies they are trying to employ.

\section{Acknowledgements}

I wish to thank Joan Jamieson for her constructive feedback and guidance throughout this study. Thanks also go to two anonymous reviewers of JALT for their helpful comments and suggestions on earlier drafts. I am solely responsible for all the errors that may remain.

Naoko Taguchi, currently on educational leave from the ESL Department of Minnesota State University-Akita, is pursuing her Ph.D. in Applied Linguistics at Northern Arizona University. Her research interest includes interlanguage pragmatics, learning strategies, and discourse analysis.

\section{Notes}

1. An earlier version of this paper was presented at the annual Second Language Acquisition Research Forum (SLRF) at the University of Wisconsin in September 2000.

\section{References}

Aneiro, S. (1989). The influence of receiver apprehension in foreign language learners on listening comprehension among Puerto Rican college students. Unpublished doctoral dissertation, New York University, New York.

Bachman, L. F. (1990). Fundamental considerations in language testing. Oxford: Oxford University Press.

Baker, L., \& Brown, A. L. (1984). Metacognitive skills and reading. In P. David (Ed.), Handbook of reading research (pp. 353-394). New York: Longman.

Brown, J. D. (1990). The use of multiple $t$ tests in language research. TESOL Quarterly, 24, 770-772.

Brown, J. D. (1996). Testing in language programs. Upper Saddle River, NJ: Prentice Hall.

Buck, G. (1990). Introspection on listening-test taking. Language Testing, 8, 67-91.

Carrell, P. L. (1989). Metacognitive awareness and second language reading. The Modern Language Journal, 73, 121-133. 
Chamot, A. U., Kupper, L., \& Impink-Hernandez, M. V. (1988). A study of learning strategies in foreign language instruction: Findings of the longitudinal study. Rosslyn,VA: Interstate Research Associates.

Chamot, A. U., \& O'Malley, J. M. (1987). The cognitive academic language learning approach: A bridge to the mainstream. TESOL Quarterly, 21, 227-249.

Clark, M. (1980). The short circuit hypothesis of ESL reading. The Modern Language Journal, 64, 203-209.

Cohen, A. D. (1998). Strategies and processes in test taking and SLA. In L. F. Bachman \& A. D. Cohen (Eds.), Interfaces between second language acquisition and language testing (pp. 90-111). Cambridge: Cambridge University Press.

Cohen, A. D. (2000). The learner's side of ESL: Where do styles, strategies, and tasks meet? Paper presented at the Southeast TESOL Meeting, Miami, Florida.

Cohen, A. D., Weaver, S. J., \& Li, T-Y. (1996). The impact of strategies-based instruction on speaking a foreign language. CARLA Working Paper Series No. 4. Minneapolis: Center for Advanced Research on Language Acquisition, University of Minnesota.

Cohen, J. (1988). Statistical power analysis for the behavioral sciences (2nd ed.). New York: Academic Press.

Conrad, L. (1985). Semantic versus syntactic cues in listening comprehension. Studies in Second Language Acquisition, 1, 59-72.

Derry, S. J., \& Murphy, D. A. (1986). Designing systems that train learning ability: From theory to practice. Review of Educational Research, 56, 1-39.

Focal Skills Resources (1990). The Focal Skills Assessments of English Proficiency. Plano, TX60: Focal Skills Resources.

Gardner, R. C., \& MacIntyre, P. D. (1992). A student's contributions to second language learning. Part I: Cognitive variables. Language Teaching, 22, 211220.

Gardner, R. C., \& MacIntyre, P. D. (1993). A student's contributions to second language learning. Part II: affective variables. Language Teaching, 26, 1-11.

Hatch, E., \& Lazaraton, A. (1991). The research manual: Design and statistics for applied linguistics. Boston: Heinle \& Heinle Publishers.

Howell, D. C. (1997). Statistical methods for psychology (4th ed.). Belmont, CA: Wadsworth Publishing Company.

Jaeger, R. M. (1993). Statistics: A spectator sport (2nd ed.). Newbury Park, CA: Sage.

Krashen, S. D. (1985). The input hypothesis: Issue and implications. London: Longman.

Mendelsohn, D. (1995). Applying learning strategies in the second/foreign language listening comprehension lesson. In D. Mendelsohn \& J. Rubin (Eds.), A Guide for the teaching of second language listening (pp. 132-150). San Diego: Dominie Press. 
Mueller, D. J. (1986). Measuring social attitudes: A handbook for researchers and practitioners. New York: Teachers College, Columbia University.

Nagle, S., \& Sanders, S. (1986). Comprehension theory and second language pedagogy. TESOL Quarterly, 20, 9-26.

O'Malley, J. M., \& Chamot, A. U. (1990). Learning strategies in second language acquisition. Cambridge: Cambridge University Press.

O’Malley, J. M., Chamot, A. U., \& Kupper, L. (1989). Listening comprehension strategies in second language acquisition. Applied Linguistics, 29, 331-341.

O'Malley, J. M., Chamot, A. U., \& Walker, C. (1987). Some applications of cognitive theory to second language acquisition. Studies in Second Language Acquisition, 9, 287-306.

Oxford, R. (1990). Language Learning Strategies: What every teacher should know. New York: Newbury House.

Oxford, R., \& Crookall, D. (1989). Research on language learning strategies: Methods, findings, and instructional issues. The Modern Language Journal, 73, 404-419.

Rost, M., \& Ross, S. (1991). Learner use of strategies in interaction: Typology and teachability. Language Learning, 41, 235-273.

Rubin, J. (1987). Learner strategies: Theoretical assumptions, research history and typology. In A. Wenden \& J. Rubin (Eds.), Learner strategies in language learning (pp. 15-30). Englewood Cliffs, NJ: Prentice Hall.

Rubin, J. (1994). A review of second language listening comprehension research. The Modern Language Journal, 78, 199-221.

SPSS. (1998). SPSS base 8.0 applications guide. Chicago: SPSS.

Thomspon, I., \& Rubin, J. (1996). Can strategy instruction improve listening comprehension? Foreign Language Annals, 29, 331-341.

Tsui, A., \& Fullilove, J. (1998). Bottom-up or top-down processing as a discriminator of L2 listening performance. Applied Linguistics, 19, 432-451.

Vandergrift, L. (1996). The listening comprehension strategies of core French high school. The Canadian Modern Language Review, 52, 200-221.

Vandergrift, L. (1998). Successful and less successful listeners in French: What are the strategy differences? The French Review, 71, 370-395.

Vandergrift, L. (1999). Facilitating second language listening comprehension: Acquiring successful strategies. ELT Journal, 53, 168-173.

Vandergrift, L. (2000). Successful L2 listeners in junior high school: How do they understand? Paper presented at Annual Association of Applied Linguistics conference, Vancouver, Canada.

Vogely, A. (1995). Perceived strategy use during performance on three authentic listening comprehension tasks. The Modern Language Journal, 79, 41-56.

Vogely. A. (1998). Listening comprehension anxiety: Students' reported sources and solutions. Foreign Language Annals, 31, 33-43. 
Wenden, A. (1986). What do second-language learners know about their language learning?: A second look at retrospective accounts. Applied Linguistics, 7, 186-201.

Wenden, A., \& Rubin, J. (1987). Learner strategies in language learning. Englewood Cliffs, NJ: Prentice-Hall.

Yi'an, W. (1998). What do tests of listening comprehension test?: A retrospective study of EFL test-takers performing a multiple-choice task. Language Testing, $15,21-24$.

(Received December 26, 2000; revised June 12, 2001)

Appendix 2

Table of Specifications of the Likert-Scaled Item Section of the Listening Questionnaire

Listening Strategies (31 items total)

A. Repair (metacognitive)

B. Affective

C. Compensatory (cognitive)

C.1. Top-down strategies

C.2. Bottom-up strategies

Difficulty Elements (11 items total)
Item Numbers

$3,10,15,24,32,33,35,37$

$1,2,9,21,22,29,36,40$

$8,13,23,27,28,38,39$

$6,7,12,16,18,20,25,31$

$4,5,11,14,17,19,26,30,34,41,42$

Note: The Likert-scaled items have an ordinal measurement of 1-5. 


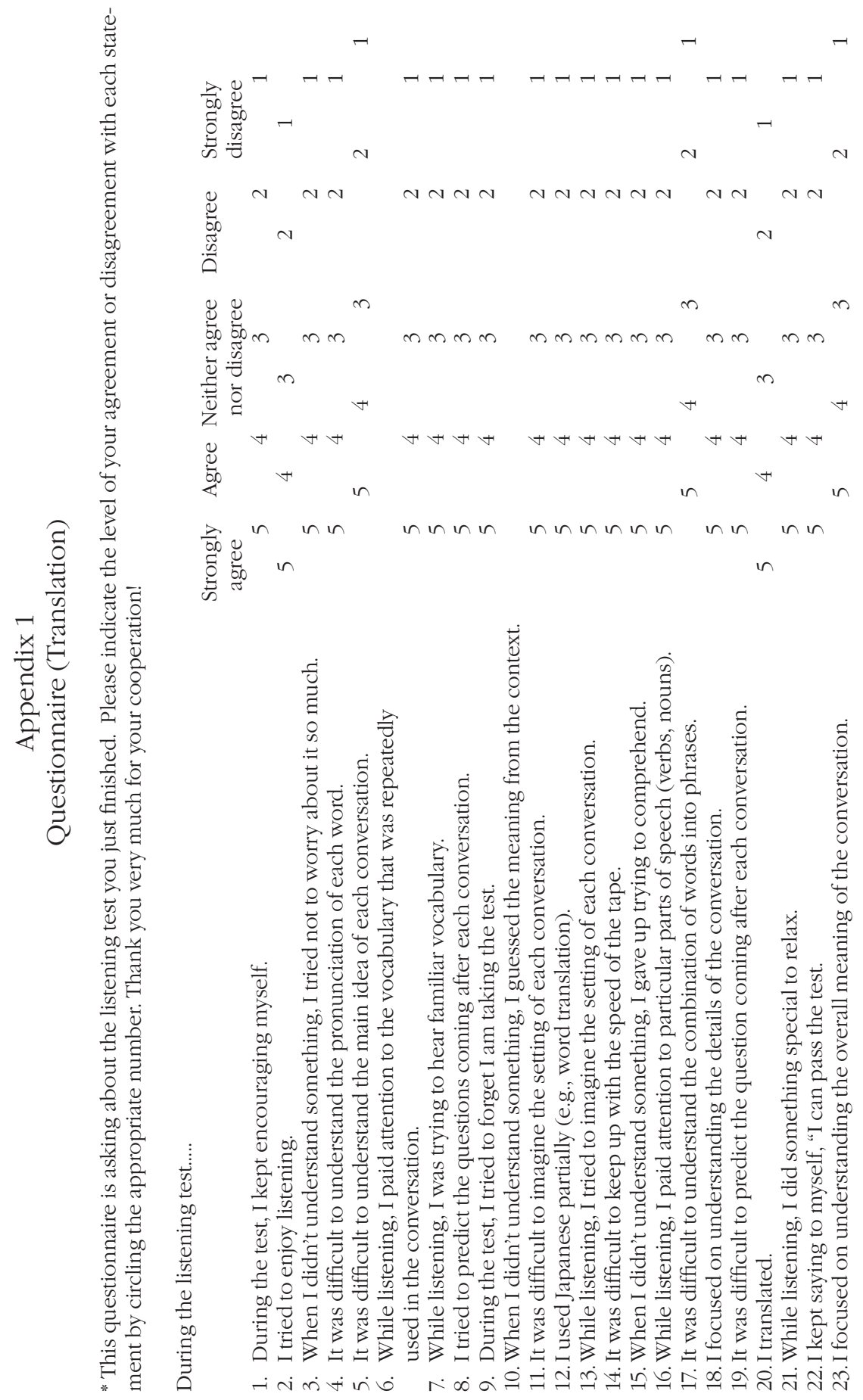


TAguchi

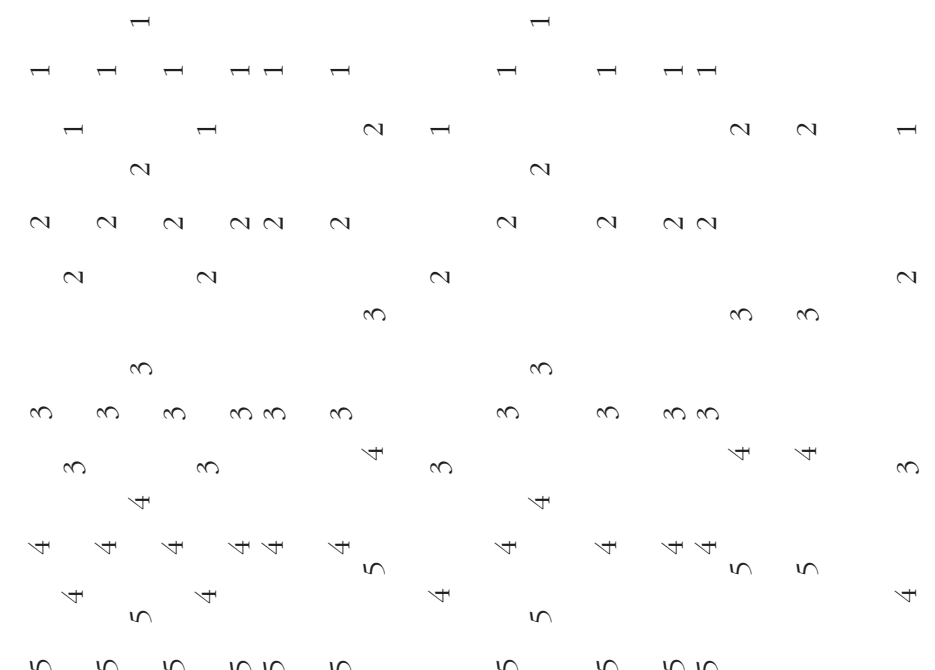

